\title{
Comparison of the protein profiles of salivary gland extracts derived from three species of unfed and partially fed ixodid ticks analysed by SDS-PAGE
}

\author{
Mirko Slovák ${ }^{1}$, Valéria Hajnická ${ }^{2}$, Milan Labuda ${ }^{1}$ and Norbert Fuchsberger $^{3}$ \\ ${ }^{1}$ Institute of Zoology, Slovak Academy of Sciences, Dúbravská cesta 9, 84206 Bratislava, Slovakia; \\ ${ }^{2}$ Institute of Preventive and Clinical Medicine, Limbová 14, 833 01, Bratislava, Slovakia; \\ ${ }^{3}$ Institute of Virology, Slovak Academy of Sciences, Dúbravská cesta 9, 84246 Bratislava, Slovakia
}

Key words: tick saliva, SDS-PAGE, Ixodes ricinus, Haemaphysalis inermis, Dermacentor reticulatus

\begin{abstract}
Salivary gland extracts (SGE) from unfed and 5 days fed adult female Ixodes ricinus (Linnaeus, 1758); Haemaphysalis inermis (Birula, 1895) and Dermacentor reticulatus (Fabricius, 1794) ticks were prepared. The protein content after feeding increased by 10.6, 8.7 and 6.8 times, respectively. Extracts were equilibrated to the same protein content and submitted to SDS-polyacrylamide gel electrophoresis followed by computer analysis of the scanned gels. Relative differences in protein profiles of extracts obtained from unfed and partially fed ticks were found in all species and some of them were similar in all three species used in the study. Results demonstrate that the increase of the protein content in salivary glands during the feeding does not occur proportionally. Some proteins are synthesised preferentially $(67.1 \mathrm{kDa}, 13.5 \mathrm{kDa})$ but other bands (in range of $15-16 \mathrm{kDa}$ ) present in the SGE derived from unfed ticks are less discernible in that of fed ticks.
\end{abstract}

Ticks are of great medical and veterinary importance not only as haematophagous ectoparasites infesting humans and domestic animals, but also as vectors of a wide variety of pathogenic organisms (see Sonenshine 1991). Ixodid ticks are obligate blood-feeders in all their life stages. In contrast to other haematophagous parasites, the contact between an ixodid tick and its host lasts for days or even weeks (Allen 1989). Therefore, besides feeding, ticks need to be tolerated by their host in order to survive. Both requirements have been solved during approximately 100 million years of evolution so that ticks are now highly adapted to their life-style. A crucial role in this adaptation is played by the salivary glands. These paired and highly complex glands are important in both feeding and immunomodulation of the host, which induces tolerance to blood feeding (Wikel $1996 \mathrm{a}, \mathrm{b})$. The salivary glands are also the primary means for transmission of tick-borne pathogens (Nuttall et al. 1994, Hajnická et al. 1998).

During feeding, the female salivary glands may increase in size about 25 fold. This process starts after a tick has sealed its mouthparts into the host skin. The process is unusual, as other haematophagous parasites are generally fully prepared for engorgement (see Sauer et al. 1995). During the prolonged feeding period, the salivary glands also increase in protein content (Wang and Nuttall 1994). Many substances have been isolated from tick saliva, e.g. cement, vasodilators, platelet aggregation inhibitors, anticoagulants, prostaglandins, and allergens (Gauci et al. 1988, Jaworski et al. 1990,
Limo et al. 1991, Wang et al. 1996, Zhu et al. 1997). However, it is not clear how changes in protein content relate to the different functions of saliva during feeding. Also, the quantitative and qualitative changes in salivary gland proteins following attachment to the host, when the tick has committed considerable resources to the feeding process, are not fully known. Ticks prior to the attachment to their host apparently do not spend the energy in preparation for complete feeding process (Sonenshine 1991). To investigate changes in the protein content of salivary glands during feeding, we compared unfed and partially fed salivary gland extracts (SGE) derived from three species which represent three different ixodid subfamilies ranging from less evolved Ixodinae - Ixodes ricinus (Linnaeus, 1758) to the most evolved Rhipicephalinae - Dermacentor reticulatus (Fabricius, 1794) with Haemaphysalinae - Haemaphysalis inermis (Birula, 1895) being in between.

\section{MATERIALS AND METHODS}

Ticks. Ticks were collected by flagging the vegetation in different localities of Slovakia. Ixodes ricinus and Dermacentor reticulatus originated from Vysoká pri Morave (Southwestern Slovakia) and Haemaphysalis inermis ticks from Čierna Dolina (Tribeč Mountain, West Slovakia). Equal numbers of tick males (4-5) and females (4-5) were placed together in plastic chambers glued on BalbC mice. Ticks were allowed to feed for 5 days. Thirty-one unfed and 26 fed female $I$. ricinus ticks, 25 unfed and 15 fed female $D$. reticulatus ticks and 37 unfed and 21 fed female $H$. inermis ticks were used. 
Preparation of SGE. Salivary glands from each group were dissected from either unfed or partially fed ticks in ice cold phosphate-buffered saline (PBS: $5 \mathrm{mM} \mathrm{Na}_{2} \mathrm{HPO}_{4} .12$ $\mathrm{H}_{2} \mathrm{O}, 1.6 \mathrm{mM} \mathrm{KK_{2 }} \mathrm{PO}_{4}, 131 \mathrm{mM} \mathrm{NaCl}, \mathrm{pH} 7.2$ ), pooled, washed three times with PBS and homogenised in a glass homogeniser in PBS containing $1 \mathrm{mM}$ phenylmethylsulphonyl fluoride. The homogenate was centrifuged at $10000 \times \mathrm{g}$ for $30 \mathrm{~min}$ at $4^{\circ} \mathrm{C}$. The concentration of total proteins in the supernatant fluid was determined using the colorimetric method according to Bradford (1976), with bovine serum albumin as the standard.

SDS-PAGE. Soluble SGEs were denatured by boiling (5 $\mathrm{min})$ in a sample buffer (125 mM Tris-HCl, $\mathrm{pH} 6.8,20 \% \mathrm{v} / \mathrm{v}$ glycerol, $4 \% \mathrm{w} / \mathrm{v}$ SDS, $10 \% \mathrm{v} / \mathrm{v} 2$-mercaptoethanol and few crystals of Bromphenol blue). SDS-PAGE with discontinuous buffer system of $\mathrm{pH} 6.8$ and 8.8 (according to Laemmli 1970) was used to separate proteins; $17 \mu \mathrm{g}$ of total protein from each pool were loaded in each lane. The gels were run at a constant current of $15 \mathrm{~mA}$ in a $4 \%$ stacking gel and at $25 \mathrm{~mA}(3 \mathrm{~mA}$ $/ \mathrm{cm}$ ) in $12 \%$ resolving gel (with an acrylamide /bisacrylamide ratio 37.5 : 1). Molecular weight standards (LMWCK, Pharmacia) phosphorylase B $(94,000)$, bovine serum albumin $(67,000)$, ovalbumin $(43,000)$, carbonic anhydrase $(30,000)$, soybean trypsin inhibitor $(20,100)$ and $\alpha$-lactalbumin $(14,400)$ were run in parallel lanes. A standard curve, constructed from their relative migration and known molecular weights, was used to estimate the molecular weight of tick proteins by means of computer program table curve. After electrophoresis, the gels were incubated overnight in a fixative solution $(40 \%$ $\mathrm{v} / \mathrm{v}$ ethanol, $20 \% \mathrm{v} / \mathrm{v}$ acetic acid) and stained with silver according to Damerval et al. (1987).

Gels were scanned using a JX-330 Sharp scanner and computer generated images were analysed by Imagemaster software (Pharmacia Biotech).

\section{RESULTS}

Although the total protein content in fed ticks was up to ten times increased, the equal amount of proteins from fed and/or unfed ticks was submitted to PAGE. This allows evaluating the relative differences between fed and unfed ticks, as well as between different tick species. The protein profiles from SGE derived from both partially fed and unfed ticks were basically similar. The number of bands (proteins) evident increased or newly synthesised in fed ticks was surprisingly small. Only the most visible differences were marked and mentioned below.

\section{SGE derived from Ixodes ricinus ticks}

The scanned couple of gels obtained by separation of SGEs prepared from unfed and fed ticks are shown in Fig. 1, computer-generated images (CGI) and its evaluation in Fig. 2 A. To obtain equal protein content in samples for PAGE the ratio between SGE from unfed and SGE from fed ticks was $10.6: 1$. Bands with the most apparent increase in quantity (or even new synthesised) correspond to the relative molecular mass of $\approx 119.8,67.1,35.0,27.6,22.9$ and $13.5 \mathrm{kDa}$,

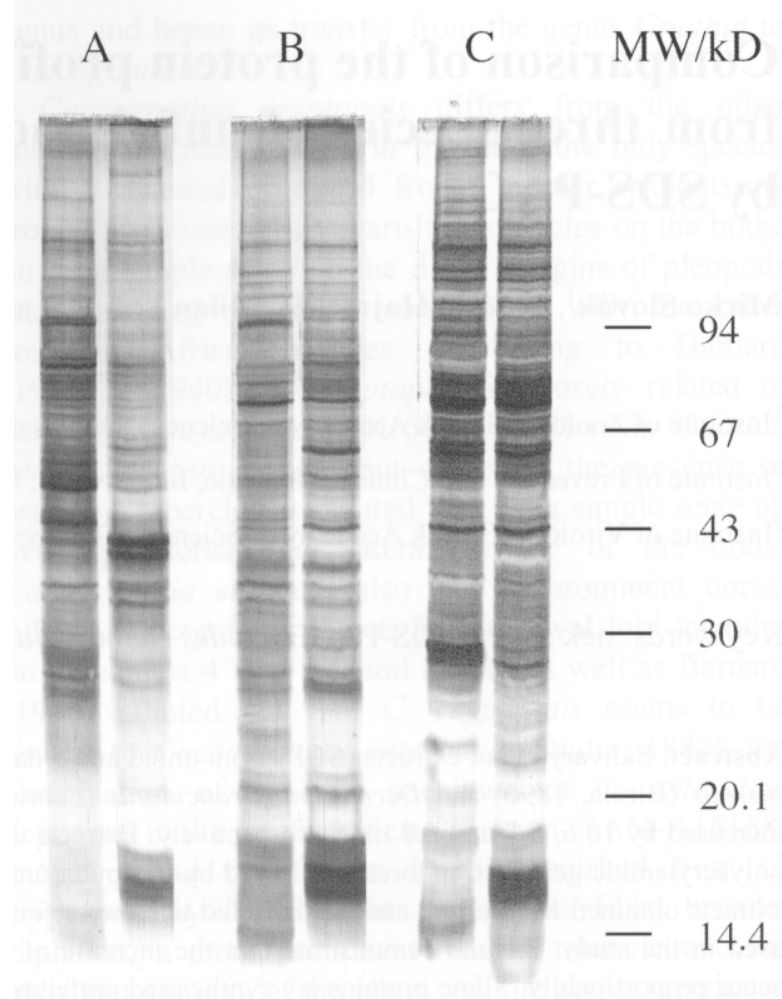

Fig. 1. Scanned couples of PAGE of salivary gland extracts derived from partially fed (left part of the couple) and unfed (right part of the couple) ticks. A - Ixodes ricinus; B Haemaphysalis inermis; $\mathbf{C}$ - Dermacentor reticulatus. Right Relative molecular weight and position of standards (Pharmacia).

respectively (Fig. 2A, black arrows, from left to the right). In contrast, higher intensity of bands corresponding to the relative molecular weight $\approx 137.6,32.7,30.2$, and $15.9 \mathrm{kDa}$, respectively, (Fig. 2A, open arrows from left to the right), indicate relatively higher amount of SGE components derived from unfed ticks.

\section{SGE derived from Haemaphysalis inermis ticks}

To obtain samples with comparable protein content the ratio of unfed/partially fed ticks was $8.7: 1$. The profiles are similar to that obtained from Ixodes ticks. Bands corresponding to relative molecular weight of $\approx 67.1,30.1,23.9$ and $13.5 \mathrm{kDa}$, respectively, represent the relative increase in respective protein content of partially fed females (Fig $2 \mathrm{~B}$, black arrows). On the other hand, the bands with molecular mass of $\approx 40.6$, 26.3 and $15.1 \mathrm{kDa}$, respectively, have higher intensity in SGE derived from unfed ticks.

\section{SGE derived from Dermacentor reticulatus ticks}

To obtain samples with comparable protein content the ratio of unfed/partially fed ticks was $6.8: 1$. Most apparent increase in band intensity corresponds to relative molecular mass of $\approx 67.1,36.0,27.6$ and 13.5 $\mathrm{kDa}$, respectively (Fig. 2C, black arrows). Bands with 

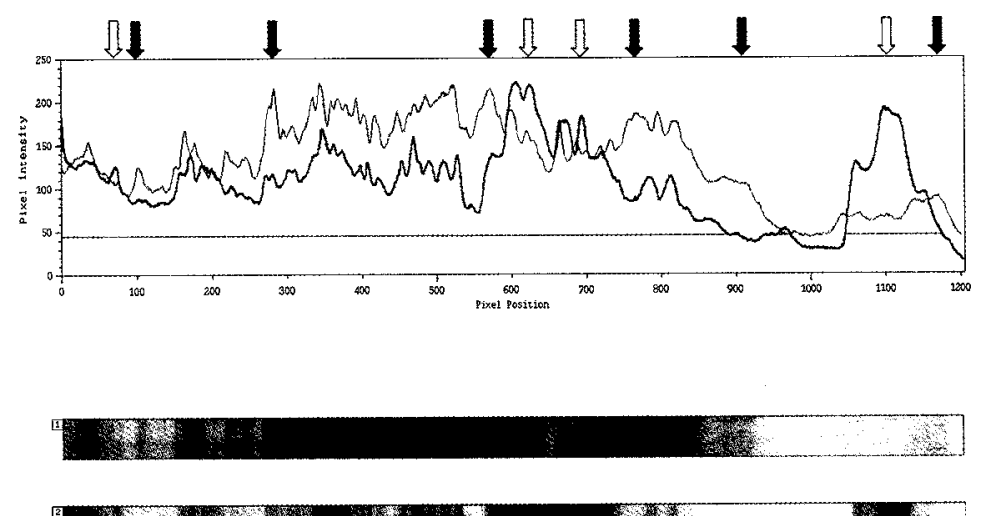

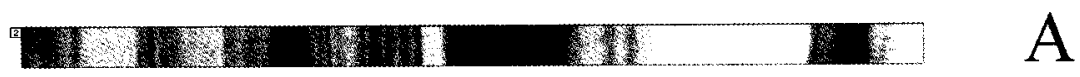
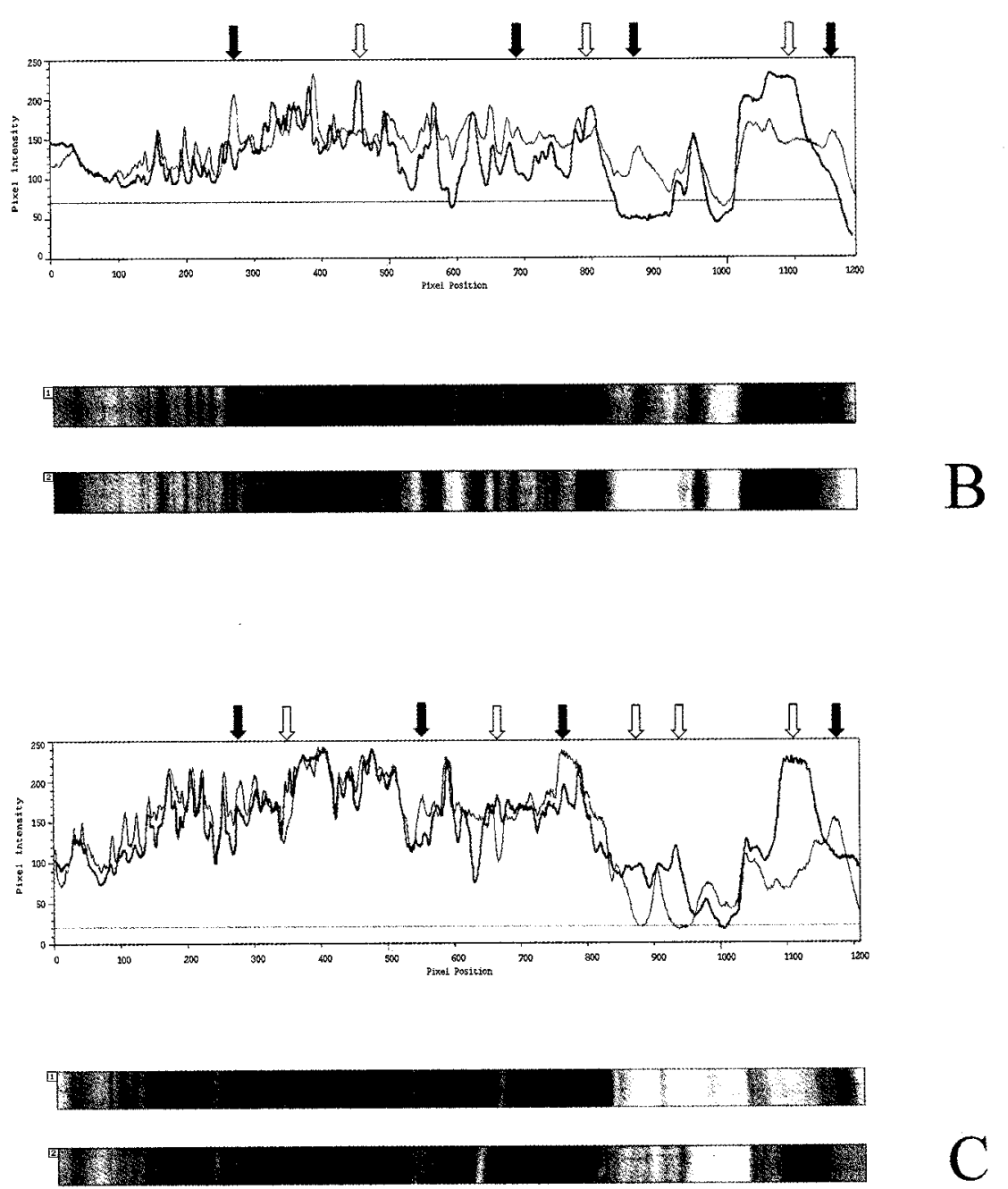

Fig. 2. Computer generated image (CGI) of scanned gels of tick salivary gland extracts matching of bands using Pharmacia Biotech Imagemaster software. 1 (upper CGI) and thin line in the mountage - partially fed ticks, 2 (lower CGI) and thick line in the mountage - unfed ticks. Arrows indicate the most markable relative differences. Arrows: black - peaks relatively higher in CGI pronounced from fed ticks, open - the same from unfed ticks. A-Ixodes ricinus; B - Haemaphysalis inermis; C-Dermacentor reticulatus. 
molecular weight of $\approx 55.4,31.2,24.1,21.915 .9$ and $15.1 \mathrm{kDa}$, respectively, are present in relatively higher amount in SGE derived from unfed ticks (Fig. 2C, open arrows).

Some changes in protein patterns of unfed and partially fed females were observed in all three tick species. The bands with molecular weight of $\approx 67.1$ and $13.5 \mathrm{kDa}$ of partially fed ticks were demonstrated in all three species. In contrast, bands showing microheterogenity, corresponding to molecular weights of $\approx 15.9$ were present in SGE derived from all unfed ticks.

\section{DISCUSSION}

One of the most notable features of ixodid ticks is the fact that in both their resting and questing stages they are not fully developed for all phases of feeding. Indeed, the development of their salivary glands occurs simultaneously with the initiation and commencement of blood feeding on their host. During the feeding salivary glands increase in weight and volume. A part of such increase occurs because the salivary glands act as an osmoregulator, removing excess water and ions taken up in the bloodmeal (see House 1980, Kaufman 1983). But at the same time the protein content increases rapidly (see also the ratio of salivary glands from unfed and partially fed ticks used to get comparable volumes of proteins for PAGE in this study). This strategy of delayed protein production is probably designed to save energy as the period prior to feeding often lasts several months or even years (Sauer et al. 1995). Therefore it is not surprising that the protein content (and the pattern of bands after electrophoresis) changes during the period of attachment on the host. However, it is not completely clear which salivary gland proteins are preferentially synthesised during feeding on the host. Although the relationship between salivary gland changes and feeding has been recognised for quite a long time, only recently have important functions of tick saliva been identified and correlated with the feeding process, e.g. the immunosuppressive activities of immunoglobulinbinding proteins and the anaesthetic and anti-inflammatory properties of histamine-binding proteins (see Nuttall 1998, Sangamnadech et al. 1998). However, most of the tick saliva activities and their correlation with the changes in salivary glands during feeding are largely unknown.
In the evaluation of the profiles obtained by SDSPAGE, it is necessary to keep in mind the higher amount of unfed ticks needed for preparation of samples with protein content comparable to that in partially fed ticks. This allows one to demonstrate the relative changes in both unfed and partially fed tick salivary glands in different tick species. Thus, all bands (and parts of profile) showing higher protein content in fed ticks represent an authentic increase of the corresponding protein content in the salivary glands of these ticks. Bands visible only in patterns from partially fed ticks may represent proteins newly synthesised during feeding or proteins present in unfed ticks in subthreshold doses. It is of interest that very few of such proteins were observed in Haemaphysalis inermis ticks compared with Dermacentor reticulatus ticks or even more prominent with Ixodes ricinus ticks. Although $H$. inermis shows a different feeding strategy ('fastfeeding' tick), the potential speculative connection with the finding mentioned above remains unknown.

In our study, some changes in protein patterns of unfed and partially fed females were, however observed in all three tick species. The increasing bands with molecular weight of $\approx 67.1$ and $13.5 \mathrm{kDa}$ of partially fed ticks were demonstrated in all three species. In contrast, the heterogeneous area of proteins with molecular weights of $\approx 15.9 \mathrm{kDa}$ was observed to disappear during the feeding of females. These may be secreted or converted to other substances during the feeding process. We have considered only the most predominant protein bands. The results do not draw attention to more subtle changes in protein patterns. Less prominent proteins, other than those emphasised here, may also change and be of physiological significance to the tick.

Previous studies suggested that dramatic changes were seen in the gland structure (Binnington 1978) and polypeptide patterns of SGE (McSwain et al. 1982) after attachment of ticks to the host.

In spite of the facts mentioned above it is possible to compare some changes in protein patterns of unfed and partially fed ticks with published data although these comparisons of polypeptides remain speculative. The identification and function of different substances produced in the salivary glands during the feeding needs further study.

\section{REFERENCES}

ALLEN J.R. 1989: Immunology of interactions between ticks and laboratory animals. Exp. Appl. Acarol. 7: 5-13.

BINNINGTON K.C. 1978: Sequential changes in salivary gland structure during attachment and feeding of the cattle tick, Boophilus microplus. Int. J. Parasitol. 8: 97-115.
BRADFORD M.M. 1976: A rapid and sensitive method for the quantitation of microgram quantities of protein utilizing the principle of protein-dye binding. Anal. Biochem. 72: 248-254.

DAMERVAL C., LE GUILLOUX M., BLAISONNEAU J., de VIENNE D. 1987: A simplification of Heukeshoven 
and Dernick's silver staining of proteins. Electrophoresis 8: $158-159$

GAUCI M., STONE B.F., THONG Y.H. 1988: Isolation and immunological characterisation of allergens from salivary glands of the Australian paralysis tick Ixodes holocyclus. Int. Arch. Allergy Appl. Immunol. 87: 208-212.

HAJNICKÁ V., FUCHSBERGER N., SLOVÁK M., KOCÁKOVÁ P., LABUDA M., NUTTALL P.A. (1998): Tick salivary gland extracts promote virus growth in vitro. Parasitology 116: 533-538

HOUSE R.C. 1980: Physiology of invertebrate salivary glands. Biol. Rev. 55: 417-473.

JAWORSKI D.C., MULLER M.T., SIMMEN F.A., NEEDHAM G.R. 1990: Amblyomma americanum: identification of tick salivary gland antigens from unfed and early feeding females with comparisons to Ixodes dammini and Dermacentor variabilis Exp. Parasitol. 70: 217-226.

KAUFMAN W.R. 1983: The function of tick salivary glands. In: K.F. Harris (Ed.), Current Topics in Vector Research. Vol. I. Praeger Scientific, New York, pp. 215-247.

LAEMMLI U.K. 1970: Cleavage of structural proteins during the assembly of the head of bacteriophage T4. Nature 227: 680-685.

LIMO M.K., VOIGT W.P., TUMBO-OERI A.G., NJOGU R.M., OLE-MOIYOI O.K. 1991: Purification and characterization of an anticoagulant from the salivary glands of the ixodid tick Rhipicephalus appendiculatus. Exp. Parasitol. 72: 418-429.

McSWAIN J.L., ESSENBERG R.C., SAUER J.R. 1982: Protein changes in the salivary glands of the female lone star tick, Amblyomma americanum during feeding. J. Parasitol. 68: 100-106.
NUTTALL P.A. 1998: Displaced tick-parasite interactions at the host interface. Parasitology 116: S65-S72.

NUTTALL P.A., JONES L.D., LABUDA M., KAUFMAN W.R. 1994: Adaptations of arboviruses to ticks. J. Med. Entomol. 31: 1-9.

SANGAMNADECH S., PAESEN G.C., SLOVÁK M., RANDOLPH S.E., NUTTALL P.A. 1998: A histaminebinding protein from Dermacentor reticulatus. In: Program and Abstract Book, $10^{\text {th }}$ Int. Congr. Acarol. 5-10 July 1998, Canberra, Australia, p. 198

SAUER J.R., McSWAIN J.L., BOWMAN A.S., ESSENBERG R.C. 1995: Tick salivary gland physiology. Annu. Rev. Entomol. 40: 245-267.

SONENSHINE D.E. 1991: Biology of Ticks. Vol. 1. Oxford University Press, New York - Oxford, $447 \mathrm{pp}$.

WANG X., COONS L.B., TAYLOR D.B., STEVENS S.E., GARTNER T.K. 1996: Variabilin, a novel RGDcontaining antagonist of glycoprotein IIb-IIIa and platelet aggregation inhibitor from the hard tick Dermacentor variabilis. J. Biol. Chem. 271: 17785-17790.

WANG H., NUTTALL P.A. 1994: Comparison of the proteins in salivary glands, saliva and haemolymph of Rhipicephalus appendiculatus female ticks during feeding. Parasitology 109: 517-523.

WIKEL S.K. 1996a: Tick modulation of host cytokines. Exp. Parasitol. 84: 304-309.

WIKEL S.K. 1996b: Host immunity to ticks. Annu. Rev. Entomol. 41: 1-22.

ZHU K., BOWMAN A.S., BRIGHAM D.L., ESSENBERG R.C., DILLWITH J.W., SAUER J.R. 1997: Isolation and characterization of americanin, a specific inhibitor of thrombin, from the salivary glands of the lone star tick Amblyomma americanum (L.). Exp. Parasitol. 87: 30-38.

Accepted 15 September 1999 